\title{
Antimicrobial resistance profiles of microorganisms isolated from hospitalized patients in Dominican Republic
}

\author{
David de Luna, ${ }^{1}$ José Javier Sánchez, ${ }^{2}$ Miguel Peguero, ${ }^{2}$ Wilmary García, ${ }^{2}$ Sylmari Liciaga, ${ }^{2}$ \\ Frank Brito, ${ }^{2}$ Pamela Fernández, ${ }^{2}$ Arlette Frías, ${ }^{2}$ Audrey Richard, ${ }^{2}$ Patricia Etienne Marie, ${ }^{2}$ \\ Yori Roque, ${ }^{1}$ and Silvia Calo ${ }^{3}$
}

Suggested citation de Luna D, Sánchez JJ, Peguero M, García W, Liciaga S, Brito F, et al. Antimicrobial resistance profiles of microorganisms isolated from hospitalized patients in Dominican Republic. Rev Panam Salud Publica. 2020;44:e36. https://doi.org/10.26633/ RPSP.2020.36

ABSTRACT Objective. To define the antimicrobial resistance profiles of the microorganisms most commonly isolated from hospitalized adult patients in Dominican Republic (DR).

Methods. A retrospective, cross-sectional study of phenotypic antimicrobial susceptibility patterns was conducted using data from 3802 clinical microbiology reports specifying positive bacterial cultures in samples collected from patients admitted to the clinical, surgery, and intensive care units (ICU) at three tertiary-level care hospitals in the city of Santiago de los Caballeros from 1 January 2016 - 31 December 2017. Descriptive statistics and chi-square test $(P \leq 0.05)$ were used to analyze the qualitative variables.

Results. At the three hospitals, there were 932, 1 090, and 1780 microbiology reports analyzed. Of the total, 1274 were from the ICU, 1042 from the surgery unit, and 1486 from the clinical unit. Methicillin resistance was found in $57.3 \%$ of the Staphylococcus aureus isolates and $75.3 \%$ of the coagulase-negative staphylococci. Third-generation cephalosporin resistance was detected in $54.4 \%$ of isolates identified as members of the Enterobacteriaceae family, $67.3 \%$ of the Acinetobacter spp., and $91.7 \%$ of the Pseudomonas, while carbapenem resistance was shown by $8.0 \%, 23.8 \%$, and $51.0 \%$ of these, respectively. Most of the resistant Acinetobacter spp. isolates were found in just one hospital and the prevalence of Enterobacteriaceae resistant to carbapenems was highest in the ICU.

Conclusion. Antimicrobial resistance levels are high among hospitalized patients in Dominican Republic and may cause enhanced risk factors that impact clinical outcomes. Urgent measures are needed to address antimicrobial resistance in DR.

Keywords Drug resistance, microbial; methicillin-resistant Staphylococcus aureus; Enterobacteriaceae; Pseudomonas; Acinetobacter; Dominican Republic.

Antimicrobial resistance (AMR) poses a major threat to public health around the world. It has clear, negative effects on people's lives and makes a substantial economic impact. Currently, at least 50000 lives per year are lost prematurely to AMR in Europe and the United States of America, alone (1). At

\footnotetext{
1 Hospital Metropolitano de Santiago, Santiago, Dominican Republic.

2 School of Health, Pontificia Universidad Católica Madre y Maestra, Santiago, Dominican Republic.
}

this rate, by 2050 AMR would reduce global economic output by an estimated US\$ 100 trillion and cause at least 300 million deaths $(1-3)$.

The World Health Organization (WHO) developed The Global Action Plan on Antimicrobial Resistance (4) based on

\footnotetext{
School of Natural and Exact Sciences, Pontificia Universidad Católica Madre y Maestra, Santiago, Dominican Republic. $\triangle$ Silvia Calo, s.calo@ce.pucmm. edu.do
} 
five main strategies to deal with AMR. These include improving alert systems and increased understanding of bacterial resistance, as well as strengthening surveillance systems, strategies echoed by other international authorities (3 - 6). In Latin America, since 1996, the Latin American Antimicrobial Resistance Surveillance Network (ReLAVRA), with the support of WHO/ Pan American Health Organization (PAHO) has been collecting information on selected resistant pathogens from reference laboratories in 19 Member States. Only a few of these countries have active national surveillance plans. However, local susceptibility patterns and surveillance programs are essential to facilitating diagnoses, infection control, and selection of the best treatment options $(1,3,7,8)$.

In addition, WHO has published a global list of antibioticresistant bacteria (9) to prioritize research and development of new antibiotic treatments. Among those top human pathogens, methicillin-resistant Staphylococcus aureus (MRSA), now endemic in the community, presents critical therapeutic difficulties due to its high adaptability $(10,11)$. In Latin America, $45 \%$ of the $S$. aureus isolates from nine countries collected in 2011 - 2014 showed methicillin resistance, but with important regional variations. Those same isolates exhibited high rates of resistance to other commonly-used antibiotics (12).

Other important pathogens on the WHO list are the Enterobacteriaceae family and Pseudomonas aeruginosa. In a study published in 2017, members of the Enterobacteriaceae family showed a high prevalence of production of extended spectrum $\beta$-lactamase (ESBL) enzymes in Latin America and the Caribbean, especially Escherichia coli and Klebsiella spp. (13). Additionally, $26 \%$ of the $P$. aeruginosa isolates exhibited a multidrug-resistant (MDR) phenotype (13). None of the studies included isolates from Dominican Republic (DR), where reliable and comprehensive AMR information is scarce despite the country being a ReLAVRA member. A short report published recently analyzed resistance patterns of microorganisms isolated from pediatric patients in DR (14). It reported that $50 \%$ of the gram-negative bacteria were resistant to at least one third-generation cephalosporin; $17 \%$ to one or more carbapenem drugs; and for S. aureus isolates, 58\% were resistant to methicillin (14). Given these elevated rates, it seems imperative to collect comprehensive information on the extent of the problem.

In essence, the significant rise in the prevalence of infections caused by resistant microorganisms is one of the greatest threats to the public health system in DR, as well as globally. These infections are associated with increased cost in medical care, longer hospital stays, and higher morbidity and mortality rates $(3,15)$. Although AMR incidence is higher in developing countries than developed ones $(16,17)$, there is much less information on AMR dynamics in developing countries $(18,19)$, including DR. Thus, to provide additional, accurate information on AMR in DR, this study sought to establish the resistance profiles of the most common pathogenic bacteria isolated from patients in three of the country's tertiary-level hospitals over 2 years.

\section{MATERIALS AND METHODS}

A retrospective, cross-sectional study of phenotypic antimicrobial susceptibility patterns was carried out with clinical samples from adult patients (17 years of age or older), hospitalized in the clinical, surgery, and Intensive Care (ICU) units of three hospitals in DR. The three hospitals are tertiary referral centers in Santiago de los Caballeros, the country's second largest city. Hospital size ranged from 170 - 400 beds. All culture-positive reports of patients hospitalized from 1 January 2016 - 31 December 2017 were collected for the study. Sample sources comprised various clinical specimens: abscess / secretions $(30 \%)$, urethral secretions $(28 \%)$, blood $(12 \%)$, urine $(12 \%)$, sputum or bronchial secretion $(6 \%)$, catheters $(6 \%)$, stool $(2 \%)$, and others $(3 \%)$. Each of the three hospitals performed sample collection according to its approved and standardized protocols. Bacterial cultures were performed following the manufacturer's instructions for automated bacterial identification and antibiotic susceptibility testing. Two of the hospitals' microbiology laboratories used VTEK ${ }^{\circledR}{ }^{\circledR}$ (BioMérieux, Durham, NC, United States) and the other used MicroScan ${ }^{\circledR}$ (Beckman Coulter, Atlanta, GA, United States). Bacterial culture reports with more than one isolate were excluded from the study. Streptococcus spp. samples were not included since only one of the three centers could perform the technically-complex tests for these isolates. The antimicrobial susceptibilities were interpreted based on the Clinical and Laboratory Standards Institute (CLSI) Performance Standards for Antimicrobial Susceptibility Testing M100 criteria (20). The data were collected from the hospitals' databases and the qualitative variables were analyzed using descriptive statistics performed with IBM SPSS ${ }^{\circledR}$ Statistics software, version 24 (IBM Corp., Armonk, NY, United States). Chi-square was used to test for statistical significance $(P \leq 0.05)$.

Ethics. This research was approved by the Faculty of Health Sciences Bioethics Committee (COBEFACS: MEd-019-1-1718). To avoid any putative harm, a letter code (A, B, or $C$ ) was assigned to identify each of the three hospitals.

\section{RESULTS}

Of the 5481 culture reports collected, 1679 were excluded due to either missing data, more than one growth in the sample, or having a microorganism species that represented less than $0.5 \%$ of the total. In all, 3802 reports were included in the analysis. Of these 932 (24.5\%) were from Health Institution A (HI-A): 347 (37.2\%) from the surgery unit, 315 (33.8\%) from the clinical unit, and $270(29 \%)$ from the ICU. From Health Institution B (HI-B), 1090 (28.7\%) reports were analyzed: 276 (25.3\%) from the surgery unit, 550 (50.5\%) from the clinical unit, and 264 (24.2\%) from the ICU. The remaining $1780(46.8 \%)$ reports were from Health Institution C (HI-C): 419 (23.5\%) from the surgery unit, $621(34.9 \%)$ from the clinical unit, and $740(41.6 \%)$ from the ICU.

Table 1 represents the most commonly identified microorganisms, some grouped by genus. As expected, Escherichia coli, Klebsiella pneumoniae, P. aeruginosa, and Acinetobacter baumannii were the most representative species of their respective genus (data not shown). Gram-negative microorganisms were identified in $79.2 \%$ of the 3802 reports analyzed. The Gram-positive bacteria were represented only by $S$. aureus (SA) and coagulase-negative staphylococci (CoNS).

Members of the Enterobacteriaceae family were the most frequently reported $(57.9 \%-81.3 \%)$, but with some differences among the three hospitals (Figure 1). Interestingly, in HI-B, Staphylococcus spp. represented $39.7 \%$ of the total isolates ( $15.7 \%$ for SA and $24 \%$ for CoNS), while Acinetobacter spp. was 
TABLE 1. Reported microorganisms isolated from patients hospitalized at three tertiary care hospitals in Dominican Republic, by medical unit, 1 January 2016 - 31 December 2017

\begin{tabular}{|c|c|c|c|c|}
\hline Microorganism & Intensive care (\%) & Surgery $(\%)$ & Clinical $(\%)$ & Total $(\%)$ \\
\hline Escherichia & $225(17.70)$ & $306(29.40)$ & $779(52.40)$ & $1310(34.50)$ \\
\hline Klebsiella & $241(18.90)$ & $186(17.90)$ & $239(16.1)$ & $666(17.50)$ \\
\hline Coagulase-negative staphylococci & $198(15.50)$ & $136(13.10)$ & $100(6.70)$ & $434(11.40)$ \\
\hline Staphylococcus aureus & $127(10.00)$ & $143(13.70)$ & $85(5.70)$ & $355(9.30)$ \\
\hline Enterobacter & $66(5.20)$ & $46(4.40)$ & $38(2.60)$ & $150(3.90)$ \\
\hline Pseudomonas & $160(12.60)$ & $47(4.50)$ & $45(3.00)$ & $252(6.60)$ \\
\hline Acinetobacter & $102(8.00)$ & $35(3.40)$ & $31(2.10)$ & $168(4.40)$ \\
\hline Shigella & $38(3.00)$ & $36(3.50)$ & $30(2.00)$ & $104(2.70)$ \\
\hline Kluyvera & $16(1.30)$ & $22(2.10)$ & $29(2.00)$ & $67(1.80)$ \\
\hline Serratia & $25(2.00)$ & $22(2.10)$ & $17(1.10)$ & $64(1.70)$ \\
\hline Cedecea & $17(1.30)$ & $18(1.70)$ & $17(1.10)$ & $52(1.40)$ \\
\hline Proteus mirabilis & $20(1.60)$ & $10(1.00)$ & $22(1.50)$ & $52(1.40)$ \\
\hline Citrobacter & $10(0.80)$ & $9(0.90)$ & $17(1.10)$ & $36(0.90)$ \\
\hline Raoultella ornithinolytica & $8(0.60)$ & $11(1.10)$ & $14(0.90)$ & $33(0.90)$ \\
\hline Morganella morganii & $7(0.50)$ & $6(0.60)$ & $10(0.70)$ & $23(0.60)$ \\
\hline Providencia & $6(0.50)$ & $4(0.40)$ & $10(0.70)$ & $20(0.50)$ \\
\hline Salmonella & $5(0.40)$ & $4(0.40)$ & $1(0.10)$ & $10(0.30)$ \\
\hline Burkholderia cepacia & $3(0.20)$ & $1(0.10)$ & $2(0.10)$ & $6(0.20)$ \\
\hline TOTAL & $1274(100)$ & $1042(100)$ & $1486(100)$ & $3802(100)$ \\
\hline
\end{tabular}

FIGURE 1. Microorganisms most frequently isolated from patients hospitalized in three tertiary care hospitals (A, B, C) in Dominican Republic, 1 January 2016 - 31 December 2017

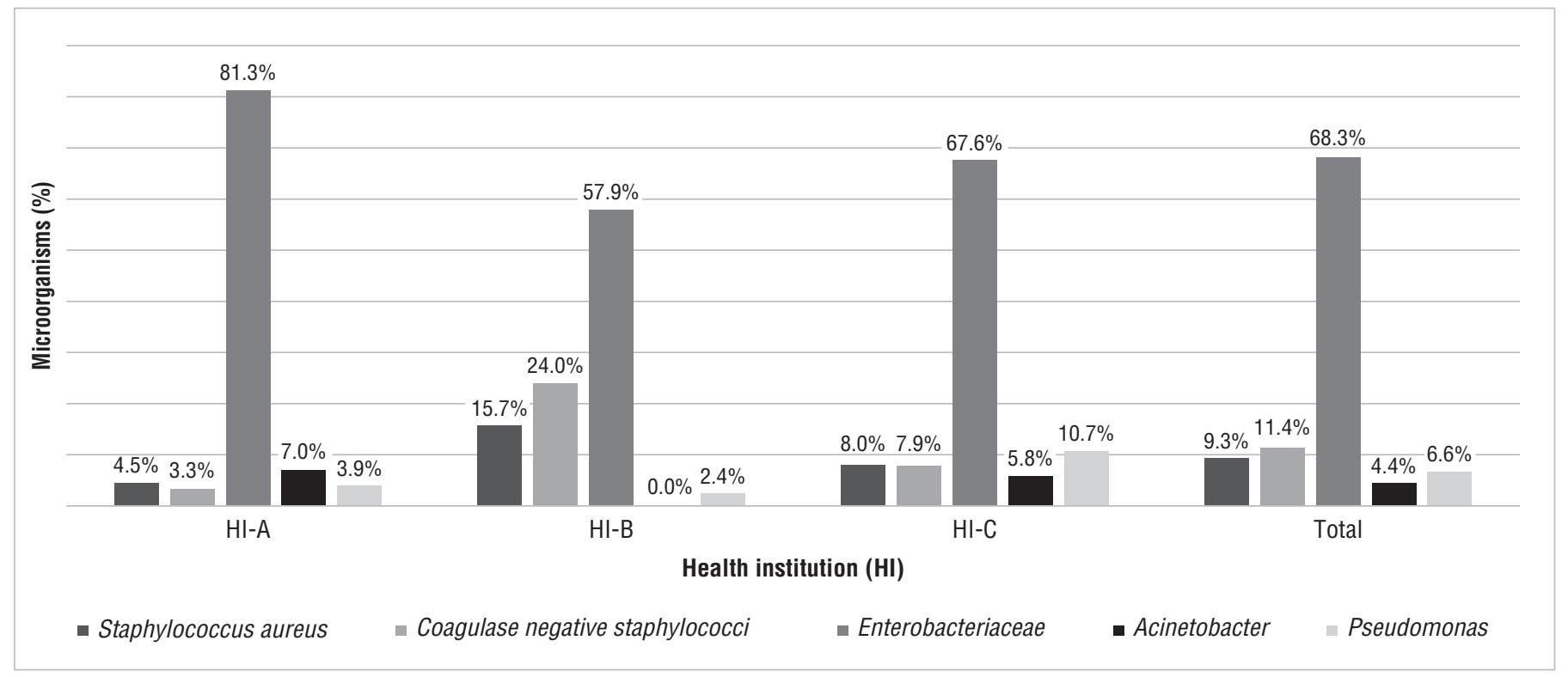

Source: Prepared by the authors from the study results.

completely absent. HI-C had the highest percentage $(10.7 \%)$ of Pseudomonas (Figure 1).

The patterns of resistance to specific antibiotics were evaluated (Figure 2a): CoNS showed higher resistance to methicillin $(75 \%)$ than did SA (57\%). Among the Enterobacteriaceae and Acinetobacter, the frequency of resistance to one third-generation cephalosporin (3GC), ceftriaxone, was found to be elevated for both groups (54.5\% and $67.3 \%$, respectively, Figure $2 b$ ). The patterns of resistance to 3GC among the different genus of the Enterobacteriaceae family did not differ much: $51.1 \%$ of Escherichia spp., $55.6 \%$ of Klebsiella spp., and $57.3 \%$ of Enterobacter spp. On the other hand, as ceftriaxone is not effectively active against Pseudomonas, resistance to ceftazidime was analyzed among those isolates. Most (91.7\%) exhibited the resistant phenotype. 
FIGURE 2. Antibiotic resistance patterns of (a) staphylococci or (b) Gram-negative rods isolated from patients hospitalized in three tertiary care hospitals in Dominican Republic, 1 January 2016 - 31 December 2017

(a)

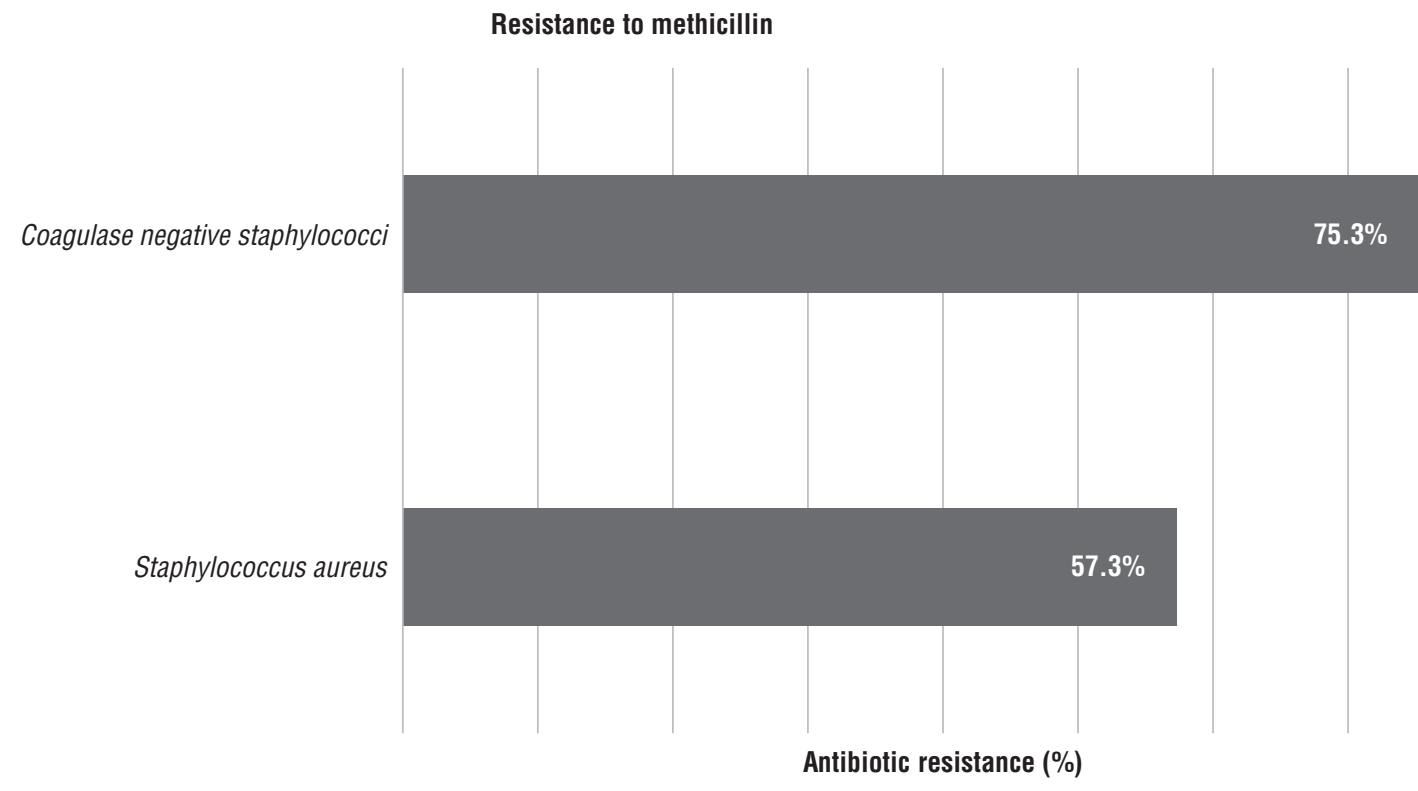

(b)

Resistance to carbapenems and cephalosporins

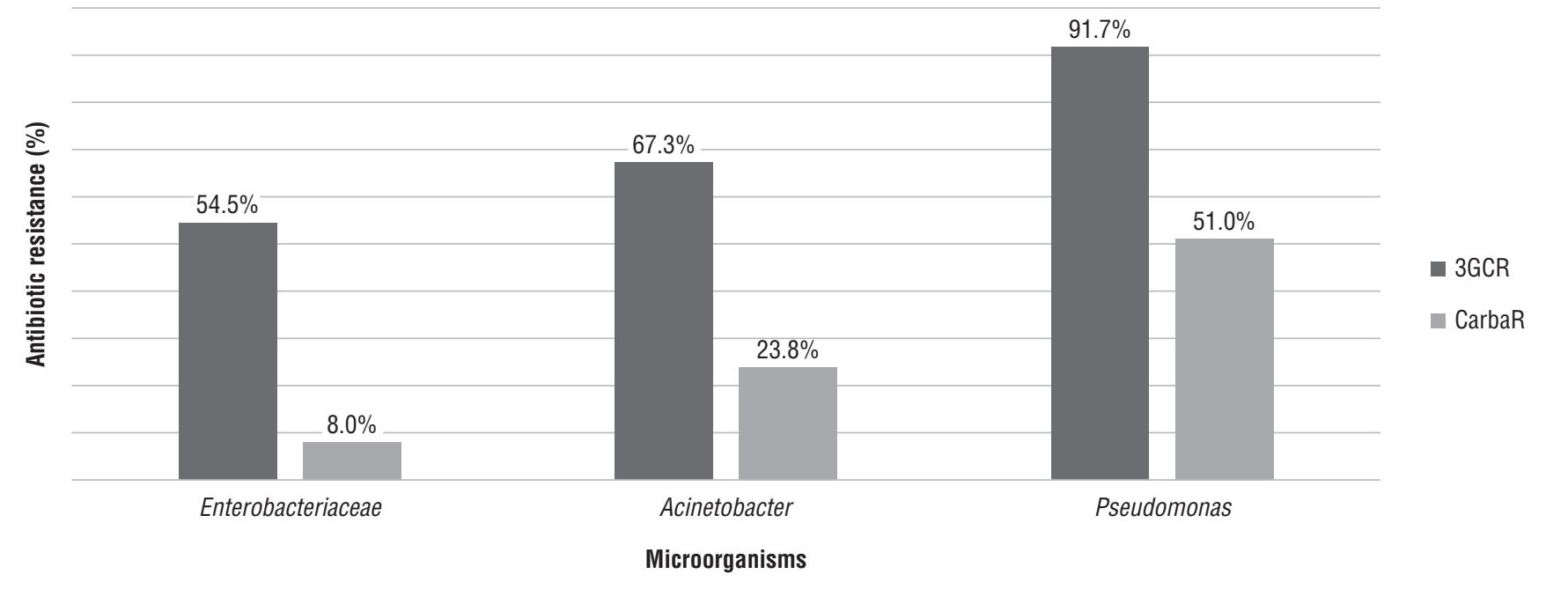

Note: Abbreviations: $3 G C R=$ third-generation cephalosporin resistance; CarbaR = carbapenem resistance Source: Prepared by the authors from the study results.

Then, resistance to at least one carbapenem antibiotic (CarbaR; imipenem and/or meropenem) was studied. Overall, CarbaR was relatively low for the Enterobacteriaceae family (8\%, Figure $2 \mathrm{~b})$, but with high variability among the members of the family, ranging from $1.6 \%$ of Escherichia spp. isolates to $23.3 \%$ of Enterobacter spp. Among the non-lactose fermenter bacteria, a striking $51 \%$ of $P$. aeruginosa and $23.8 \%$ of $A$. baumannii isolates analyzed were reported as CarbaR.

Figure 3 compares resistance patterns by health institution and shows significant differences among the three hospitals. CoNS isolates exhibited around $75 \%-80 \%$ of methicillin resistance in the three hospital settings, while MRSA ranged from $49 \%$ in HI-C to $79 \%$ in HI-A ( $P=0.002)$. Resistant Enterobacteriaceae were also more frequently reported in HI-A $(P \leq 0.001)$. On the other hand, 3GC resistant Acinetobacter, CarbaR Acinetobacter, and CarbaR Pseudomonas isolates were predominant in HI-C versus the other hospitals: $96.1 \%$ versus $0 \%-21.5 \%$ for 3 GC resistant Acinetobacter $(P \leq 0.001)$; $35.9 \%$ versus $0 \%-4.6 \%$ for CarbaR Acinetobacter ( $P \leq 0.001)$; and $58.2 \%$ versus $23.1 \%-33.3 \%$ for CarbaR Pseudomonas $(P \leq 0.001)$. HI-C also reported that more than $95 \%$ of its Pseudomonas were resistant to third-generation cephalosporins. 
FIGURE 3. Antibiotic resistance patterns of microorganisms isolated from patients hospitalized in three tertiary care hospitals in Dominican Republic, 1 January 2016 - 31 December 2017

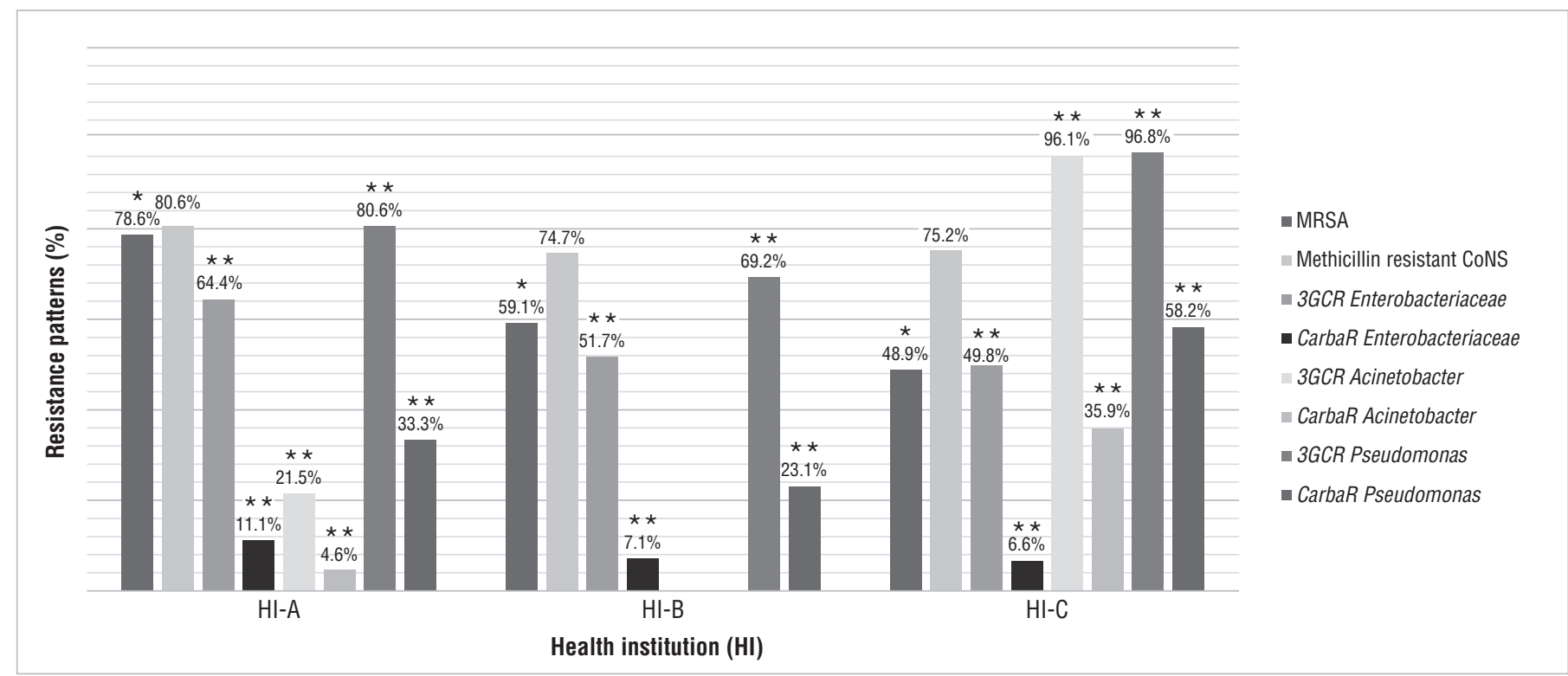

Note: The chi-square test analyzed the differences for each resistant phenotype among the three institutions. ${ }^{*} P=<0.05,{ }^{* \star} P=<0.001$. Other $\mathrm{P}$-values: $P=0.769$ for methicillin-resistant CoNS. Abbreviations: MRSA = methicillin resistant Staphylococcus aureus; CoNS = coagulase-negative staphylococci; $3 G C R=$ third-generation cephalosporin resistance; CarbaR = carbapenem resistance. Source: Prepared by the authors from the study results.

Furthermore, Escherichia spp. and Klebsiella spp. were the most commonly isolated microorganisms in the three units (Table 1): Escherichia spp. represented $17.7 \%$ of the total isolated microorganisms from the ICUs, $29.4 \%$ from surgery units, and $52.4 \%$ from clinical units; while Klebsiella spp. was present less frequently in the three units $(16 \%-19 \%)$. Pseudomonas spp. and Acinetobacter spp. were more frequently isolated from the ICU, with $12.6 \%$ and $8.0 \%$ of the total, respectively, while in the other units it ranged from $2.1 \%-4.5 \%$ (Table 1 ). The distribution of $S$. aureus among the three units varied: $5.7 \%$ in clinical, $10 \%$ in the ICU, and $13.7 \%$ in surgery (Table 1 ).

Finally, the resistance patterns of the various microorganisms were organized by unit (Figure 4). MRSA was less-commonly isolated from the ICU, with $42 \%$ versus $61 \%-69 \%(P<0.001)$. By contrast, CarbaR Enterobacteriaceae were more frequently reported in the ICU, with $20.4 \%$ versus $2 \%-6 \%(P<0.001)$. However, CarbaR Pseudomonas, 3GC-resistant Pseudomonas, and 3GC-resistant Enterobacteriaceae were less frequently found in the clinical units $(16 \%, 82 \%$, and $49 \%$, respectively) than in the ICUs $(63 \%, 94 \%$, and $62 \%$, respectively), or even the surgery units $(43 \%, 92 \%$, and $57 \%$, respectively). The remaining phenotypes analyzed showed similar patterns of resistance in the three medical units (Figure 4).

\section{DISCUSSION}

This is the first descriptive report of common pathogens and their antibiotic resistance patterns, isolated from adult patients hospitalized in three medical units within three different hospitals in DR. This study found that the frequency of the microorganisms (Figure 1) was similar to what has been observed throughout Latin America (13), except for Streptococcus spp. which could not be analyzed due to a lack of testing by clinical microbiology labs in DR.
The slight discrepancies observed in the pattern of microorganisms reported by the three hospitals (Figure 1) could be explained by multiple factors, e.g., different sample collection protocols, different patient populations, and/or the sample's source. For example, HI-C had a higher number of samples isolated from the ICU than did the other two hospitals $(41.6 \%$ vs. $29 \%$ in HI-A and $24 \%$ in HI-B), and both Pseudomonas and Acinetobacter are more commonly isolated from the ICU (Table $1)$, which would explain why they are more frequent in $\mathrm{HI}-\mathrm{C}$ (Figure 1). However, HI-B showed the highest prevalence of staphylococci isolates $(39.7 \%$ vs. $7.8 \%$ in $\mathrm{HI}-\mathrm{A}$ and $15.9 \%$ in HI-B, Figure 1) and the highest proportion of samples collected from its clinical unit (50\% vs. $34 \%$ in HI-A and 35\% in $\mathrm{HI}-\mathrm{C}$ ), although it was the unit with the lowest frequency of staphylococci isolates $(12.4 \%$ vs. $25.5 \%$ in the ICU and $26.8 \%$ in the surgery unit, Table 1). In addition, several other factors known to affect health care facilities in developing countries should be considered: resource limitations, lack of trained personnel, and infection control measures, among others (21). These could lead to an institutional bias on the tested microorganisms, or even the possibility of contaminating samples with colonizing species, which could cause disparities among health institutions.

To define resistance to 3GC, susceptibility to ceftriaxone (or ceftazidime for Pseudomonas isolates) was analyzed following the CLSI specifications (20). Resistance to 3GC was quite elevated in all the microorganisms analyzed $(54.5 \%-91.7 \%$, Figure 2). When microorganisms, such as E. coli or K. pneumoniae, show resistance to one or more of the extended-spectrum cephalosporins (ceftazidime and ceftriaxone included), the medical community suspects production of ESBL, according to CLSI criteria (20). This would indicate that the three study hospitals have a considerably high prevalence of ESBL, although ESBL-specific tests would be necessary for confirmation. Nevertheless, Latin American countries usually have the highest 
FIGURE 4. Antibiotic resistance patterns of microorganisms isolated patients hospitalized in three tertiary care hospitals in Dominican Republic, by medical unit, 1 January 2016 - 31 December 2017

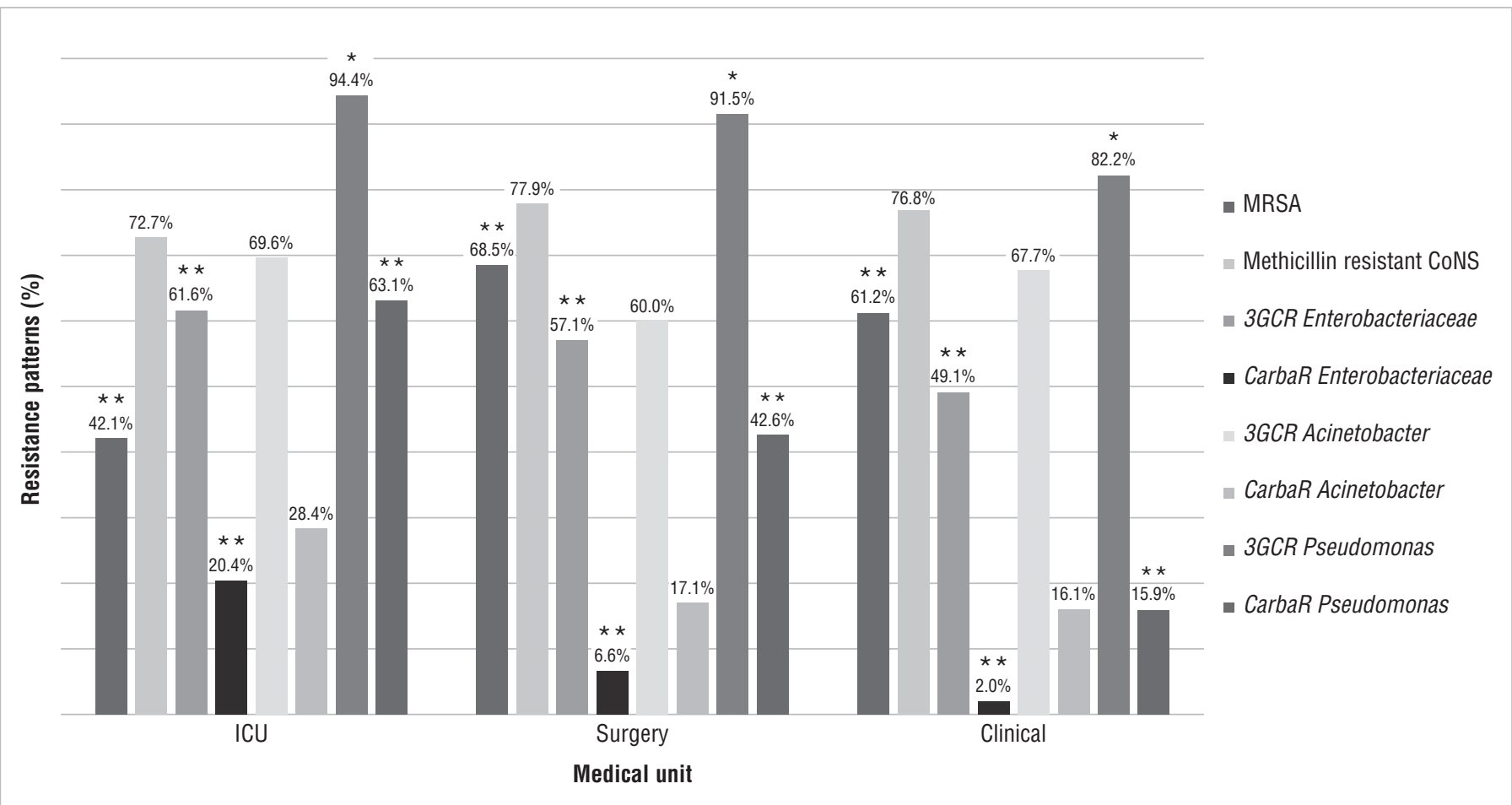

Note: The chi-square test analyzed the differences for each resistant phenotype among the three medical units. ${ }^{\star} P=<0.05,{ }^{*} P=<0.001$. Other $P$-values: $P=0.515$ for methicillin-resistant CoNS; $P=0.578$ for 3GCR Acinetobacter; $P=0.216$ for CarbaR Acinetobacter. Abbreviations: ICU = Intensive Care Unit; MRSA = methicillin resistant Staphylococcus aureus; CoNS = coagulase-negative staphylococci; $3 \mathrm{GCR}=$ third-generation cephalosporin resistance; CarbaR = carbapenem resistance.

Source: Prepared by the authors from the study results.

rates of ESBL producers, globally $(22-24)$. These data suggest that patients in DR may have an enhanced risk factor impacting their clinical outcome, which could include inappropriate empirical antibiotic therapy, a longer hospital stay, hospitalization in the ICU, and death $(1,3,23)$.

Regarding Pseudomonas, the study found phenotypes with notably elevated resistance to both ceftazidime and meropenem (91.7\% and 51\%, respectively, Figure 2). In other Latin American countries, $70.0 \%$ and $64.2 \%$ susceptibility rates to those drugs were reported for $P$. aeruginosa isolates (25), while only $9.1 \%$ of carbapenem-resistant $P$. aeruginosa isolates were found in a surveillance study of five cities in the United States in 2015 (26). Furthermore, a high prevalence of health care-associated infections caused by $A$. baumannii resistant to imipenem was associated with overuse of fluoroquinolones and carbapenems (27). Additionally, the presence of MDR bacteria can lead to the overuse of broad-spectrum antibiotics (27). Consequently, the reported rate of carbapenems-resistance among our non-lactose fermenter bacteria could be causing an over-prescribing of broad-spectrum antibiotics (i.e., cephalosporins, fluroquinolones, carbapenems) in health care institutions, exacerbating the AMR threat in DR. Therefore, it is imperative to perform a complete analysis of the underlying molecular mechanisms and the extent of their spread to raise awareness among the public, health authorities, and decision-makers.

Methicillin resistance was also found to be high in our study (57.3\%, Figure 2). MRSA prevalence in the Latin America is usually elevated $(40 \%-45 \%)$, but with an important regional variation. In a 2009 study, the rate of detected MRSA ranged from $20 \%$ in Nicaragua to $80 \%$ in Peru and Chile among nosocomial infections (28). In a 2017 study (12), the highest prevalence of MRSA was found in hospitals in Brazil (62\%), Venezuela (57\%), and Mexico (57\%) (12). Thus, DR would be among the countries with the highest reported MRSA prevalence according to the most recent reports. When the different institutions were compared, HI-A was the hospital with least $S$. aureus isolates reported (42), but the highest MRSA prevalence (79\%), while HI-B and HI-C had more S. aureus isolates (171 and 142), but a lower percentage of MRSA detected (59\% and $49 \%$, respectively). Further analysis of the underlying phenomenon causing these discrepancies is needed to understand if, for example, a local anomaly or differences in standard operating procedures are responsible.

As shown by Figure 3, resistance patterns differ at the three hospitals, despite all being tertiary-level and located in the same city. Surveillance systems are essential for providing the information needed to develop local therapy guidelines and antibiotic control policies $(29$ - 31). Moreover, adequate surveillance would enable individual health care centers to take action against various risk factors and weaknesses to reduce the spread of MDR bacteria and prevent outbreaks (31).

\section{Limitations}

This study had three main limitations. First, because the three hospitals were the only centers in the region with databases of 
microbiological reports, the study scope was limited to patients hospitalized at tertiary-level facilities. Second, study samples at the three hospitals were not tested for resistance to the same antibiotics; thus, only data from routinely-tested resistance could be analyzed. Third, demographic data and clinical presentation were not assessed; therefore, further analysis is necessary to determine the most accurate treatment of choice.

\section{Conclusions}

This multicenter study analyzed a large number of microbiological reports over a relatively long timeframe. It is the first published study of antibiotic resistance patterns of microorganisms isolated from hospitalized adults in DR. Factors considered to exacerbate AMR are over and misuse of antibiotics due to over-prescription, self-medication, and over-the-counter sales; the absence of standardized guidelines for antibiotic usage; and poor sanitation and hygiene $(3,18,32-34)$. Since these factors are widespread in DR, it was not surprising to find high levels of antibiotic resistance.

These findings provide relevant information to the medical and scientific community working on AMR locally, regionally, and even globally. Health authorities and decision-makers in DR must undertake broad and urgent measures to tackle AMR, and hopefully this report will instigate the first steps toward joining The Global Action Plan on Antimicrobial Resistance.

Author contributions. DL conceived the original idea for this study. MP, WG, SL, FB, PF, AF, AR, and PEM collected the data. All authors analyzed the data. DL, JJS, YR and SC interpreted the results. DL and SC wrote the paper. YR and JJS reviewed the manuscript. All authors reviewed and approved the final version.

Acknowledgements. We would like to thank the three hospitals and the staff in the microbiology labs for allowing and helping us to collect the data. We also thank FE Nicolás for critical reading.

\section{Conflicts of interest. None declared.}

Disclaimer. Authors hold sole responsibility for the views expressed in the manuscript, which may not necessarily reflect the opinion or policy of the RPSP/PAJPH and/or PAHO.

\section{REFERENCES}

1. O'Neill J. Tackling drug-resistant infections globally: final report and recommendations. In: Ro A, editor., ed. Resistance. London, United Kingdom: 2016;1,84. Available from: https://amr-review. org/sites /default / files/160518_Final\%20paper_with\%20cover. pdf. Accessed 25 October 2019.

2. Martens E, Demain AL. The antibiotic resistance crisis, with a focus on the United States. J Antibiot (Tokyo). 2017;70(5):520-6. doi:10.1038/ja.2017.30

3. Aslam B, Wang W, Arshad MI, Khurshid M, Muzammil S, Rasool $\mathrm{MH}$, et al. Antibiotic resistance: a rundown of a global crisis. Infect Drug Resist. 2018 Oct 10;11:1645-58.

4. World Health Organization, Global Action Plan on Antimicrobial Resistance. Geneva: WHO; 2015. Available from: https:/ / apps.who. int/iris/bitstream/handle/10665/193736/9789241509763_eng. pdf? sequence=1\&isAllowed=y Accessed 25 October 2019.

5. World Health Organization, Antibiotic resistance. geneva: WHO; 2018. Available from: https://www.who.int/en/news-room/factsheets/detail/antibiotic-resistance. Accessed 25 October 2019.

6. Center for Disease Control and Prevention. Antibiotic Resistance: A Global Threat. Atlanta: CDC; 2018. Avaliable online: https:// www.cdc.gov/features/antibiotic-resistance-global/index.html. Accessed 25 October 2019.

7. Fadare JO, Ogunleye O, Iliyasu G, Adeoti A, Schellack N, Engler D, et al. Status of antimicrobial stewardship programmes in Nigerian tertiary healthcare facilities: Findings and implications. J Glob Antimicrob Resist. 2019 Jun;17:132-6.

8. Hijazi K, Joshi C, Gould IM. Challenges and opportunities for antimicrobial stewardship in resource-rich and resource-limited countries. Expert Rev Anti Infect Ther. 2019 Aug;17(8):621-34.

9. Rello J, Kalwaje Eshwara V, Lagunes L, Alves J, Wunderink RG, Conway-Morris A, et al. A global priority list of the TOp TEn resistant Microorganisms (TOTEM) study at intensive care: a prioritization exercise based on multi-criteria decision analysis. Eur J Clin Microbiol Infect Dis. 2019 Feb;38(2):319-23.

10. Naber CK. Staphylococcus aureus Bacteremia: Epidemiology, Pathophysiology, and Management Strategies . Clin Infect Dis. 2009 May 15;48 Suppl 4:S231-7.

11. Monaco M, Pimentel de Araujo F, Cruciani M, Coccia EM, Pantosti A. Worldwide epidemiology and antibiotic resistance of Staphylococcus aureus. In: Curr Top Microbiol Immunol. 2017;409:21-56.
12. Arias CA, Reyes J, Carvajal LP, Rincon S, Diaz L, Panesso D, et al. A prospective cohort multicenter study of molecular epidemiology and phylogenomics of Staphylococcus aureus bacteremia in nine Latin American countries. Antimicrob Agents Chemother. 2017 Sep 22;61(10).

13. Vega S, Dowzicky MJ. Antimicrobial susceptibility among Gram-positive and Gram-negative organisms collected from the Latin American region between 2004 and 2015 as part of the Tigecycline Evaluation and Surveillance Trial. Ann Clin Microbiol Antimicrob. 2017 Jul 12;16(1):50.

14. de Luna D, Sánchez JJ, López M, Pérez M del C, Cabán L, Roque Y, et al. Antibiotic resistance profile in intrahospital pediatric services at third level centers in Dominican Republic. Infectio. 2020;24(2):66-70.

15. World Health Organization. The evolving threat of antimicrobial resistance: Options for action. Geneva: WHO Publ; 2012. Available from: https://apps.who.int/iris/bitstream/handle/10665/ 44812/9789241503181_eng.pdf? sequence=1\&isAllowed=y. Accessed 25 October 2019.

16. Klein EY, Van Boeckel TP, Martinez EM, Pant S, Gandra S, Levin $\mathrm{SA}$, et al. Global increase and geographic convergence in antibiotic consumption between 2000 and 2015. Proc Natl Acad Sci USA. 2018 Apr 10;115(15)E3463-70.

17. Collignon P, Beggs JJ, Walsh TR, Gandra S, Laxminarayan R. Anthropological and socioeconomic factors contributing to global antimicrobial resistance: a univariate and multivariable analysis. Lancet Planet Health. 2018 Sep;2(9):e398-e405.

18. Rousham EK, Unicomb L, Islam MA. Human, animal and environmental contributors to antibiotic resistance in low-resource settings: Integrating behavioural, epidemiological and one health approaches. Proc Biol Sci. 2018 Apr 11;285(1876).

19. Vikesland P, Garner E, Gupta S, Kang S, Maile-Moskowitz A, Zhu N. Differential Drivers of Antimicrobial Resistance across the World. Acc Chem Res. 2019 Apr 16;52(4):916-24.

20. Clinical and Laboratory Standards Institute. Performance standards for antimicrobial susceptibility testing. 27th ed. supplement M100. CLSI: Wayne, PA; 2017.

21. Okeke IN, Laxminarayan R, Bhutta ZA, Duse AG, Jenkins P, $\mathrm{O}^{\prime}$ Brien TF, et al. Antimicrobial resistance in developing countries. Part I: Recent trends and current status. Lancet Infect Dis. 2005 Aug;5(8):481-93. 
22. Guzmán-Blanco M, Labarca JA, Villegas MV, Gotuzzo E. Extended spectrum $\beta$-lactamase producers among nosocomial Enterobacteriaceae in Latin America. Braz J Infect Dis. 2014 Jul-Aug;18(4):421-33.

23. Oliveira MC, Oliveira CRA, Gonçalves KV, Santos MS, Tardelli ACS, Nobre VA. Enterobacteriaceae resistant to third generation cephalosporins upon hospital admission: Risk factors and clinical outcomes. Braz J Infect Dis. 2015 May-Jun;19(3):239-45.

24. Adler A, Katz DE, Marchaim D. The Continuing Plague of Extended-spectrum $\beta$-lactamase-producing Enterobacteriaceae Infections. Infect Dis Clin North Am. 2016 Jun;30(2):347-75.

25. Pfaller MA, Shortridge D, Sader HS, Gales A, Castanheira M, Flamm RK. Ceftolozane-tazobactam activity against drug-resistant Enterobacteriaceae and Pseudomonas aeruginosa causing healthcare-associated infections in Latin America: report from an antimicrobial surveillance program (2013-2015). Braz J Infect Dis. 2017 Nov-Dec;21(6):627-37.

26. Walters MS, Grass JE, Bulens SN, Hancock EB, Phipps EC, Muleta D, et al. Carbapenem-Resistant Pseudomonas aeruginosa at US Emerging Infections Program Sites, 2015. Emerg Infect Dis. 2019 Jul;25(7):1281-8.

27. Tan CK, Tang HJ, Lai CC, Chen YY, Chang PC, Liu WL. Correlation between antibiotic consumption and carbapenem-resistant Acinetobacter baumannii causing health care-associated infections at a hospital from 2005 to 2010. J Microbiol Immunol Infect. 2015 Oct; 48(5):540-4.

28. Guzmán-Blanco M, Mejía C, Isturiz R, Alvarez C, Bavestrello L, Gotuzzo E, et al. Epidemiology of meticillin-resistant Staphylococcus aureus (MRSA) in Latin America. Int J Antimicrob Agents. 2009 Oct;34(4):304-8.
29. Tacconelli E, Sifakis F, Harbarth S, Schrijver R, van Mourik M, Voss A, et al. Surveillance for control of antimicrobial resistance. Lancet Infect Dis. 2018 Mar;18(3):e106.

30. Castanheira M, Deshpande LM, Mendes RE, Canton R, Sader HS, Jones RN. Variations in the occurrence of resistance phenotypes and carbapenemase genes among enterobacteriaceae isolates in 20 years of the SENTRY antimicrobial surveillance program. Open Forum Infect Dis. 2019 Mar 15;6(Suppl 1):S23-S33.

31. Zarpellon MN, Viana GF, Mitsugui CS, Costa BB, Tamura NK, Aoki $\mathrm{EE}$, et al. Epidemiologic surveillance of multidrug-resistant bacteria in a teaching hospital: A 3-year experience. Am J Infect Control. 2018 Apr;46(4):387-92.

32. Center for Disease Control and Prevention. Antibiotic Resistance Threats in the United States, 2019. Atlanta: CDC;2019. Available from: https://www.cdc.gov/drugresistance/pdf/threats-report/2019ar-threats-report-508.pdf. Accesed on 25 October 2019.

33. The antibiotic alarm. Nature. 2013 Mar 14;495(7440):141. doi:10 1038/495141a

34. Zaman S Bin, Hussain MA, Nye R, Mehta V, Mamun KT, Hossain N. A Review on Antibiotic Resistance: Alarm Bells are Ringing. Cureus. 2017 Jun 28;9(6):e1403.

Manuscript received on 2 November 2019. Revised version accepted for publication on 18 February 2020.

\section{Perfiles de resistencia a los antimicrobianos de microorganismos aislados en pacientes hospitalizados de República Dominicana}

RESUMEN Objetivo. Determinar cuáles son los perfiles de resistencia a los antimicrobianos de los microorganismos aislados con mayor frecuencia en los pacientes adultos hospitalizados en República Dominicana.

Métodos. Se llevó a cabo un estudio retrospectivo y transversal de los patrones de fenotipos de sensibilidad a los antimicrobianos mediante el uso de los datos obtenidos en 3802 antibiogramas. Este estudio detalla cultivos de bacteria positivos en las muestras de pacientes ingresados en las unidades clínicas, quirúrgicas y de cuidados intensivos (UCI) de cada uno de los tres hospitales de atención especializada de la ciudad de Santiago de los Caballeros. El estudio se llevó a cabo del 1 de enero del 2016 al 31 de diciembre del 2017. Se recurrió a la estadística descriptiva y la prueba de la $\chi^{2}(P \leq 0,05)$ para analizar las variables cualitativas. Resultados. Se analizaron 932 antibiogramas del hospital A, 1090 del hospital B y 1780 del hospital C. Del total, 1274 resultados corresponden a las $\mathrm{UCl}, 1042$ a las unidades quirúrgicas y 1486 a las unidades clínicas. El $57,3 \%$ de las cepas aisladas de Staphylococcus aureus y el $75,3 \%$ de los estafilococos coagulasa-negativos resultó resistente a la meticilina. Se detectó que el 54,5\% de las cepas aisladas de la familia Enterobacteriaceae resultó resistente a la cefalosporina de tercera generación; en este caso, el 67,3\% del género Acinetobacter y el $91,7 \%$ del género Pseudomonas resultaron resistentes a la cefalosporina. Asimismo, se detectó que son resistentes a los fármacos carbapenémicos y se obtuvieron los resultados siguientes: 8,0\%, $23,8 \%$ y $51,0 \%$, respectivamente. La mayoría de las cepas del género Cursiva resistentes fueron identificadas en un solo hospital, mientras que en las UCI se evidenció mayor predominio de las cepas de Cursiva resistentes a los fármacos carbapenémicos.

Conclusiones. Los niveles de resistencia a los antimicrobianos demuestran ser más elevados en los pacientes hospitalizados de República Dominicana. Esto puede causar factores de riesgo intensificados que se traduzcan en consecuencias clínicas. Asimismo, es necesario establecer medidas inmediatas para abordar los casos de resistencia a los antimicrobianos en República Dominicana.

Palabras clave Farmacorresistencia microbiana; Staphylococcus aureus resistente a meticilina; Enterobacteriaceae; Pseudomonas; Acinetobacter; República Dominicana. 


\section{Perfis de resistência antimicrobiana de microrganismos isolados de pacientes hospitalizados na República Dominicana}

RESUMO Objetivo. Definir os perfis de resistência antimicrobiana dos microrganismos isolados com mais frequência em pacientes adultos hospitalizados na República Dominicana.

Métodos. Realizamos um estudo transversal retrospectivo dos padrões fenotípicos de suscetibilidade antimicrobiana utilizando dados de 3802 laudos de microbiologia clínica que especificavam culturas bacterianas positivas em amostras coletadas de pacientes internados em unidades clínicas, cirúrgicas e de terapia intensiva (UTIs) de três hospitais terciários da cidade de Santiago de los Caballeros, de 1 de janeiro de 2016 a 31 de dezembro de 2017. Para a análise das variáveis qualitativas, utilizamos estatísticas descritivas e o teste do qui-quadrado $(p \leq 0,05)$.

Resultados. Nos três hospitais, foram analisados 932, 1090 e 1780 laudos de microbiologia. Do total, 1274 foram de UTIs, 1042 de unidades cirúrgicas e 1486 de unidades clínicas. A resistência à meticilina foi encontrada em $57,3 \%$ dos isolados de Staphylococcus aureus e $75,3 \%$ dos estafilococos coagulase negativos. A resistência a cefalosporinas de terceira geração foi detectada em 54,4\% dos isolados identificados como membros da família Enterobacteriaceae, 67,3\% de Acinetobacter spp. e 91,7\% de Pseudomonas, enquanto a resistência ao carbapenem foi observada em 8,0\%, 23,8\% e 51,0\% destes isolados, respectivamente. A maioria dos isolados resistentes de Acinetobacter spp. foi encontrada em apenas um hospital, e a prevalência de Enterobacteriaceae resistentes a carbapenem foi maior nas UTIs.

Conclusão. Os níveis de resistência antimicrobiana são elevados em pacientes hospitalizados na República Dominicana e podem aumentar os fatores de risco que afetam os resultados clínicos. São necessárias medidas urgentes para abordar a resistência antimicrobiana na República Dominicana.

Palavras-chave Resistência microbiana medicamentos; Staphylococcus aureus resistente à meticilina; Enterobacteriaceae; Pseudomonas; Acinetobacter; República Dominicana. 